\title{
OBITUARIES
}

\section{Sir Edward Maclagan K.C.S.I., K.C.I.E.}

Edward Douglas Maclagan, the son of General Maclagan, R.E.; was born in the Punjab on 25th August, 1864, and died in London on 22nd October, 1952. Educated at Winchester and New College, Oxford, he passed the examination for the Indian Civil Service in 1883. In 1906 he became Chief Secretary to the Government of the Punjab, and in 1910 Secretary of the Revenue and Agricultural Department to the Government of India. From 1915-18 he was Secretary to the Education Department. In 1919 he succeeded O'Dwyer as Lieut.-Governor of the Punjab and from 1921 till 1924 was its Governor. Good sense, patent sincerity, and a remarkable gentleness of manner, which was the note of his character even during his last days of physical affliction, endeared him to all classes and well fitted him to be the healer of the Punjab's scars at a time of great stress and disturbance.

On returning to England in 1924, Sir Edward occupied himself with writing a notable book on The Jesuits and the Great Mogul (1932), and he contributed many reviews to this Society's Journal. He was its President from 1925 to 1928 , and again from 1931 till 1934, and remained a member of its Council until a long illness prevented his attendance.

Sir Edward's other great interest in retirement was the Royal Hospital and Home for Incurables, Putney, where he was not only an assiduous Vice-Chairman of the Board, but devoted many hours to visiting the patients and taking measures for their comfort. At his last visits he was wheeled, a fellow-sufferer, among those for whom he had done so much. His portrait in oils commemorates his long and tireless service to the Home. He leaves a widow and two daughters, to whom the Society extends its respectful sympathy.

R, O. WINSTEDT.

\section{Edward Butts Howell}

In 1898 Howell, aged nineteen, left Dulwich. Next year he entered the Chinese Maritime Customs Service. His ability won rapid promotion so that by 1922 he had reached the rank of Commissioner. When he retired eight years later he was in charge of Maritime Customs at Tientsin. In 1916 he had married Margaret 
McCardle. Looking back on his career in China, Howell used to say that T'êng-yüeh, on the Sino-Burmese frontier, had been the station he liked best. It was a preference that revealed his passionate love of nature and of an open-air life and his boundless zest for gathering knowledge. Tours of inspection were his chief duty while at T'êng-yüeh from 1911 to 1914. They took him through some of the wildest and most beautiful country in China and there he encountered primitive tribes and varied flora and fauna. Incidentally he discovered a new rose, afterwards called by his name. Language proficiency advanced him in the Service; because of it he was detailed more than once to conduct the periodic examinations of Customs personnel in Chinese. He was twice decorated by the Chinese Government with the Chia Ho Order, being promoted to the Third Class in 1923. Interest in Chinese psychology and former customs moved him to study the collection of forty tales, called Chin ku ch' $i$ kuan, by unknown authors early in the seventeenth century. In 1925 and the next year he published his translations of twelve of them in two volumes under the titles, The Inconstancy of Madam Chuang and The Restitution of the Bride, a notable addition to the scanty fund of Chinese fiction in translation.

After he had retired in 1930 and settled at Chalfont St. Giles, Howell continued active in sinology. As lecturer in the geography and the written language he lent his experience to the Department of Chinese Art and Archæology at the Courtauld Institute, and much we valued him. Among the Societies which profited from his advice was the Royal Asiatic; he served on the Council eight years and as Honorary Secretary two years until illness caused him to resign in 1951, the illness that ended fatally on 6th November last. His wife had predeceased him. Latterly he had volunteered to help in the Department of Oriental Antiquities in the British Museum, and spent there many days arranging and classifying a collection of netsukes. Handsome, good at games, and with great charm of manner, Howell won the affection of numerous friends.

W. Perceval Yetts.

\section{Lionel Charles Hopkins, I.S.O.}

Hopkins had been a member of the Society sixty-three years when death took him, aged nearly 98 , on 11th March last year. Most of the time since his retirement in 1908 from the Consular 